\title{
Covid 19 and Education: The Untold Story of the Barriers to Technology Adoption From A Tertiary Viewpoint
}

\author{
*Na-Ajele Gadija Williams-Buffonge \\ University of the West Indies Five Islands. Antigua West Indies \\ Liberal Arts, Antigua State College. Golden Grove. Antigua, West Indies \\ *Email of the corresponding author: najele@hotmail.com, naajele@gmail.com
}

\begin{abstract}
The Covid- 19 Pandemic has changed the way Higher learning institutions normally conduct learning. Educational technology is a learning tool that helps lecturers enhance learning through instructional practices; however, lecturers are having difficulties adopting technology. The purpose of this study was to examine the barriers that lecturers' face when attempting to adopt technology and the support needed to be successful within their instructional practices. The conceptual frameworks for this study were Bandura's self-efficacy theory and Rogers' diffusion of innovation. The study included eight lecturers from a Caribbean college in Antigua and Barbuda as participants. Data were collected through interviews and analyzed using open coding and thematic analysis. Findings from the study indicated that there were barriers that were preventing lecturers from adopting technology. These barriers included the need for professional training, institutional support, and observational learning of others which would assist with lecturers' pedagogy, content knowledge, and technology adoption. The results of the study may lead to social change by revealing potential barriers that lecturers face during technology use. The study can also provide both lecturers and stakeholders with data that is Caribbean-specific and can provide the most effective plan to support lecturers' adoption of technology.
\end{abstract}

Keywords: Barriers to Technology Adoption, Caribbean lecturers' hindrances to technology adoption, Covid19, Barriers to technology adoption in Higher Learning

DOI: $10.7176 / \mathrm{JEP} / 12-10-02$

Publication date: April $30^{\text {th }} 2021$

\section{Introduction}

The Covid-19 pandemics has changed how educational facilities around the world now conduct their classes (Daniel, 2020). University and colleges have now been forced to move to an online learning medium leaving many lecturers and students bewildered. While educational institutions use trial and error as to the best Learning Management System (LMS) some lecturer's express frustration to the roller coaster they have experienced with the multiple LMS they are required to use. Lecturers expressed that one minute they are using Zoom, then they are advised to use Goggle Classroom. Then they are told to switch to Moodle, Teams and or Blackboard Ultra. Although, all these platforms prove to have their advantages and or disadvantages lecturers have expressed their frustration and revealed their insecurities when attempting information communications Tools within their lecturers in a higher learning setting.

Lecturers are not the only person being affected by the new shift in learning but students as well. Students have expressed their frustration with the various modalities of learning but one of the constant chorus that is sung by students is the instability of the internet. The students shared often time they or their lecturers may have internet issues preventing them to understand what is being said during the lesson. This problem has caused students and or lecturer the inability to stream, use multimedia tools or engage in simulations which aim is to support learning. Students are unfamiliar with the LMS and ICT tools used due to their inexperience which hampers students learning.

Even though lecturers are committed in adopting technology there are barriers that are preventing them from becoming successful in the process. These difficulties occur even after knowing that successful adoption of educational technology can lead to changes within the learning process among students. Masingila et al. (2019) said even though technology adoption is a meaningful tool that can promote a positive learning environment in terms of students' success, if the adoption process is not done correctly, it will not provide a better learning environment for students. Despite college lecturers' interest in technology adoption, they face several challenges that prevent them from adopting technology successfully (Alemu ,2015). Khodabandelou et al. (2016), found that these challenges include teachers' lack of professional development in terms of adoption of technology. It is difficult for lecturers to integrate curriculum and technology when used together. However, lecturers continue to see technology adoption as complete and distinct from the classroom environment. Therefore, lecturers' technology competency and knowledge skills are vital in terms of instructional practices. However, if lecturers lack the confidence to use technology, then both students and lecturers may find themselves at a disadvantage within the classroom environment. 


\section{Technology Adoption}

The term technology adoption is defined as the lecturer's ability to use technology within their instructional practice to foster students' learning and promote positive student outcomes through curriculum using technology in their instructional practices (Hsu, 2010). As lecturers aspire to adopt technology, they may find hindrances that prevent them from being successful. These hindrances can be seen as barriers and may include lecturers' self-efficacy. It may be because of these barriers that college lecturers have found difficulties with the adoption process, causing adoption within the classroom to move at a slower rate. This may be a contributing factor that can influence college lecturers' technology adoption when they are attempting to use Information Communications Technology (ICT) within the classroom. A lecturer's self-efficacy is another component as to why lecturers are having difficulties. Self-efficacy is influential. It can influence a person's actions, affect their behavior, and influence how they think and behave when interacting with others (Kul, 2018).

\subsection{Barriers to Technology Adoption}

According to Khodabandelou et al. (2016), college lecturers' issues regarding technology adoption include internet connectivity failure, online course tool failure, and outdated or broken devices in computer labs. Within the Caribbean, professional development for college lecturers regarding technology use is insufficient and negatively affects college lecturers' confidence in terms of using technology (Kut, 2018; Onuoha et al., 2016). There is inadequate support when lecturers attempt to adopt technology in the classroom, and they lack time to learn new technological tools (Guzmán, 2018; Kut, 2018; Onuoha et al., 2016). Although stakeholders and persons within the Antigua and Barbuda education system believed in technology adoption, few policies support the initiative of becoming competent and adopting technology within lecturers' classroom.

This study is useful because it will fill a gap in knowledge regarding challenges college lecturers face in terms of technology adoption within their specific subject area from a Caribbean perspective. Presently, there is not much literature on college lecturers' experiences within the Caribbean regarding their technology adoption and the necessary support required with this adoption within their specific subject area. It was found that most literature was written from a western industrialized perspective, and it proved to be challenging finding current information about Latin America and other developing countries regarding technology adoption.

The study will also provide information that will influence policy and help in terms of making necessary adoption changes. Such changes could lead to policymakers supporting the technology adoption process for college lecturers and students. Once stakeholders are invested in the cause, they will be more mindful of inadequate infrastructure, resources needed, and lecturers' recommendations to bring about educational reform. Although several gaps and problems have been identified within the study, the primary focus was on lecturers' barriers to adoption

\section{CONCEPTUAL FRAMEWORK}

This study's theoretical frameworks were Bandura's self-efficacy theory and Rogers' diffusion of innovation theory. Bandura (1997) suggested that lack of competency or uncertainty in oneself and one's environment can lead to a resistance to change. This can make it difficult for technology adoption to occur. Self-efficacy influences the activities in which one engages. People's insecurities and beliefs in themselves are the fundamental cause of their successes or failures in terms of situations that they may face. This can, therefore, be a barrier to technology adoption. Based on personal perceptions, past experiences, and comfort levels, individuals perform at the level at which they feel comfortable. This theory helped to interpret issues faced by college lecturers in the United States (U.S.) and those lecturers by Caribbean college lecturers.

If college lecturers are not comfortable using technology, then implementation will be met with resistance, making adoption impossible (Arcelay-Rojas, 2018; Kale \& Goh, 2014). Many college lecturers are accustomed to using a teacher-centered approach. It may be difficult for some to learn different instructional strategies; therefore, they may resist innovation and implementation within the classroom. Arcelay-Rojas (2018) explained that a person's behavior is often governed by their perceptions of self-efficacy rather than their actual capabilities; Hence, many college lecturers may be afraid to attempt technology adoption.

Self-efficacy is how a person views their capabilities through reflection, internalization, and actions (Bandura, 1977). Xia (2017) defined self-efficacy as the ability or belief that a person has to execute an action and achieve desired outcomes. Self-efficacy influences whether individuals perform specific tasks, which then causes their learning to be controlled by a specific behavior or environmental factor (Xia, 2017). Bandura (1998) said individuals who perform at high levels have high self-efficacy and engage and participate in projects faster and more willingly than those who have low self-efficacy and are slower and disengaged. Persons with high selfefficacy believe in their capabilities and are not afraid of new challenges or difficult tasks (Lemon \& Garvis, 2016). However, individuals with low self-efficacy doubt their skills. Efficacy expectation is dependent on how much exertion is necessary to complete a task and how much time is spent working out challenges. If an individual's perceived self-efficacy is strong, they will put forth greater efforts to accomplish a task than 
individuals with low self-efficacy.

Self-efficacy is a powerful tool that can be used to predict individuals' behaviors and how they perform specific tasks. Self-efficacy is a contributing factor in terms of performing well in academics (Bandura et al., 1996; Xia, 2017). Individuals who have a strong sense of self-efficacy participate more readily in tasks and work more diligently when encountering stressful situations (Bozbayindir \& Alev, 2019; Margolis \& McCabe, 2004; Xia, 2017). Self-efficacy influences how individuals choose activities and how long they plan to engage in them (Bozbayindir \& Alev, 2019). However, although self-efficacy influences performance, it is not the sole determining factor of behavioral success, especially if an individual's will and abilities are deficient (Bandura, 1977, 1986, 1997). According to Chemers et al. (2001), when a situation is perceived as challenging or threatening, self-efficacy affects how individuals experience the relationship between situational demands and coping resources. If lecturers coping resources are insufficient, then a threat occurs, and individuals may avoid the challenge. However, if lecturers coping resources are adequate to meet situational demands, then the individual will take up the challenge. People with high self-efficacy will have the confidence to acquire enough resources to meet situational demands (Xia, 2017).

Rogers' diffusion of innovation theory is used to describe ICT adoption. Rogers (2005) stated that adoption is the ability of individuals to use an innovation to enhance their everyday life. Rogers' theory includes five main steps that influence adoption: knowledge, persuasion, decision, integration, and confirmation. Without these steps, adoption cannot take place (Rogers, 2005, 2010). Rogers (2005) said:

1. The decision-maker gains knowledge concerning a particular innovation.

2. The innovator must begin to form ideologies and attitudes concerning the innovation.

3. A decision must be made about whether to embrace or reject the innovation.

4. The innovator decides whether to implement the innovation due to the choices that occurred during the process, allowing the innovator to evaluate whether they will use the innovation.

These steps helped to determine barriers preventing lecturers' adoption of technology at a higher learning institution located in the Caribbean as well as their failures and successful experiences. Both Conceptual Framework were used to identify the phenomenon identified.

Rogers's (2003) diffusion of innovation theory is vital for this study, as it provides insight as to why college lecturers at Zendejay College may be hesitant to use new technology innovations, why some college lecturers may accept the new technology, and why others may reject using technology (Rogers, 2005, 2010). Fishbein and Ajzen (2010) stated that when adopters look at an innovation and feel that they lack the skills to use it or have negative feelings toward it, issues may arise in implementation (Lawrence \& Tar, 2018; Rusek et al., 2017).

Rogers (2003) diffusion of innovation theory also suggests that specific attributes may influence a person's likelihood of innovation adoption (Rogers, 2005, 2010). These attributes include the exposure a person may have with the innovation, their ability to use the innovation, and the person's socioeconomic status (Lawrence \& Tar, 2018; Rogers, 2005, 2010; Rusek et al., 2017). The innovation must be compatible with cultural norms, and social norms or negative attitudes may be held by the adopter (Hart \& Laher, 2015; Rogers, 2005, 2010).

\section{Review of Literature}

Research and empirical evidence have revealed the benefits and necessity of equipping students with $21^{\text {st }}$ century tools. College lecturers do not adequately adopt education technology within the classroom, preventing students from acquiring $21^{\text {st }}$ century skills needed to function adequately within the workforce. Many college lecturers know the benefits of ICT but may find it challenging to make connections when using technology at home and transferring it to the classroom (Onuoha et al., 2016). The purpose of this basic study is to understand college lecturers' beliefs regarding barriers to technology adoption experience and the necessary support that they need. By understanding barriers to ICT adoption, stakeholders will have a better idea of what policies, implementation strategies, and support are necessary for college lecturers to implement ICT in the classroom.

\subsection{Issues with Technology Adoption For College Lecturers}

Technology has proven to be the most instrumental factor in students' learning experience and the world (Alemu, 2015; Bai et al., 2016; Keengwe \& Maxfield, 2015, Durff \& Carter, 2019). Technology has brought significant benefits to the lives of individuals and has provided significant advancement to society (Alemu, 2015; Keengwe \& Maxfield, 2015; Durff \& Carter, 2019; Fargon, Smith \& Voogt, 2019). Within the context of education, ICT has taken education to a new level by reshaping how learning is being carried out and reconfiguring how teaching is displayed by college lecturers (Jarrahi, 2018). Khan et al. (2012) noted, "The use of ICT offers powerful learning environments and can transform the learning and teaching proofs so that students can deal with knowledge in an active, self-directed and constructive way" (p. 62).

Although technology benefits have been overwhelming in other fields, technology still has not displayed a tangible impact in the way it should in education (Alemu, 2015, Farjon, Smith \& Voogt, ,2019). Though educators are already aware of how technology has been impacting learning and have agreed to the 
empowerment that it provides to both students and college lecturers alike; college lecturers are having significant difficulty implementing technology within their classroom (Durff \& Carter, 2019). Kimmons and Hall (2016) stated, "When asked if school technology is cutting edge, only $10 \%$ of students, $9 \%$ of college lecturers, and 17 $\%$ of IT professionals think so" (p. 312).

Many issues prevent college lecturers from integrating technology into their classes (Alemu, 2015; Alkahtani, 2017; Kim et al., 2013; Machado \& Chung, 2015; Ramorola, 2014; Saxena, 2017). College lecturers face difficulties such as being unable to use technology effectively due to insufficient supportive infrastructure, awful internet connectivity, and the inability to connect the content with the appropriate technology to help support learning. Other issues may stem from age, attitude, cultural beliefs, lack of training and self-efficacy issues and ICT knowledge gaps, among other factors (Inan \& Lowther, 2010; Otttenbreit-Leftwich, 2010).

College lecturers have been complaining about integration issues for more than 20 years (Kurt, 2010). Technology is not being used as an instructional tool, but it is being used minimally for non-instructional tendencies (Robinson \& Wizer, 2016). Saxena (2017) shared that there are college lecturers within the school system that are presently struggling with integrating technology within a subject classroom setting. One of the many cries by college lecturers are that there is an inability to translate their knowledge of technology into a classroom setting. Consequently, this leads to a noticeable gap among college lecturers in their technology use and ICT knowledge base (Nikolopoulou \& Gialamas, 2016b). College lecturers' confidence level has been shaken, which may influence the lack of ability to promote integration within their class. With the high demands and pressures made by schools and stakeholders to promote technology, college lecturers are not receiving the required support system by the necessary institution and stakeholders, leading to a lack of integration.

To further compound the issue, stakeholders do not include the college lecturers when making ICT policies. At times, these policies may not be practical, which causes college lecturers to have a negative attitude about the process (Saxena, 2017). Not all college lecturers have the same level of technological expertise, which helps explain why not all college lecturers integrate ICT at the same rate (Nikolopoulou \& Gialamas, 2016a; Saxena, 2017; Van Niekerk \& Blignaut, 2014). In a global study that consisted of various schools nationwide, across 26 countries, Kurt (2010) revealed that the two most significant issues within secondary and primary schools were found. It was identified that there was a deficiency by teachers as to their skills and the lack of necessary training they needed to be competent to implement technology tools within the classroom effectively.

Although college lecturers accept the value of ICT integration, it may become difficult for college lecturers to manipulate ICT into the subject matter (Durff \& Carter, 2019; Robinson \& Wizer, 2016). Many preservice and in-service college lecturers lack the ability to use technology to support educational learning. This may be because they may not be technologically savvy (Durff \& Carter, 2019; Ramorola, 2014). College lecturers may also have difficulties following the new technological trends such as blogs, wikis, podcasting, and animation creation. The need for support is pivotal, and many of these educators may have none at the educational institution they work at (Ramorola, 2014). ICT should be included in the curriculum and should not be used in isolation of the curriculum (King et al., 2019; Ramorola, 2014).

\subsection{Barriers to Technology Adoption}

Within the integration process, college lecturers are instrumental and necessary. There is no question that technology plays an essential role in educational success sustainability (Kearney et al., 2018; Ozerbas \& Erdogan, 2016). College lecturers' and their technology adoption practices and lessons learned can lead to solutions as to how to better understand the integration process. A barrier can be defined as anything that prevents a specific objective from occurring. Within the area of technology adoption, studies have demonstrated that college lecturers appreciate the importance of technology adoption and how it is valuable to students' motivation while promoting students' engagement (Castro \& Nyvang, 2018; Ottenbreit-Leftwich et al., 2010). Even though this may be so, college lecturers are experiencing considerable difficulties in the integration process due to barriers (Ertmer et al., 1999). For these reasons, researchers have been driven to gain an in-depth understanding of 'the various factors that contribute to technology adoption (Castro, 2016; Castro \& Nyvang, 2018).

Some of the most common barriers are lecturer-related variables that include the self-confidence of college lecturers and the lecturer's belief in the usefulness of the technology (Hur et al., 2016; Tondeur et al., 2016). However, leadership is a factor in technology adoption (Becuwe et al., 2016). Other researchers have shown that barriers can be categorized into many parts. Durff and Carter (2019) divided them according to technical support and skills, pedagogical beliefs, and tolls and infrastructure.

Ertmer et al. (1999) broke the barriers down further into first-order (external factors) and second-order (internal factors) barriers. Ertmer et al. described the first-order barriers as being external to the lecturer. This includes a lack of adequate equipment, support from technical support, training, and knowledge (Chen, 2012; Ertmer et al., 1999; Hew \& Brush, 2007). Second-order barriers are hindrances to technology adoption. These include school-level factors, an organization's culture, lecturer-level factors, and college lecturers' beliefs (Tsai 
\& Chai, 2012). The last barrier, according to Tsai and Chai (2012), is the third-order barrier. This barrier refers to the lack of design and thinking skills by college lecturers (Özdemir, 2017; Tsai \& Chai, 2012).

Barriers can stand alone or be interrelated. However, by removing these barriers, college lecturers will be further helped with the adoption process. If college lecturers remove their first-order barrier, they will become more encouraged using technology (Castro \& Nyvang, 2018; Tsai \& Chai, 2012). If the second-order barrier is removed, college lecturers will be more dedicated to technology empowerment for the students and be more committed to using and promoting a positive attitude to change toward technology (Tsai \& Chai, 2012). By removing the third barrier, college lecturers will be competent with their technology use, allowing them to readably be able to use technology when needed without any issues. Barriers will always be present. However, understanding the various barriers and their causes will allow for a better grasp into technology adoption.

\subsection{New Ways of Learning}

The shift of traditional learning has been apparent in many higher learning institutions, especially with the changes that digital technology and educational technologies have provided students (Delgado et al., 2015; Fu, 2013; Hart \& Laher, 2015). These digital technologies have shaped education and have supported both lecturers and students in facilitating learning (Delgado et al., 2015; Hart \& Laher, 2015). These tools have transformed learning and prepared students for the world of work (Smith, 2020). The tools help students practice new concepts and allow for a holistic type of learning within the classroom, which will develop students' knowledge base using various forms of technology (Smith, 2020).

According to Januszewski and Molenda (2008), educational technology is defined as "the study of ethical practice of facilitating learning and improving performance by creating, using and managing appropriate technological processes and resources" (p. 1). The primary goal of educational technology is to help others learn. Learning has always been the final product of educational technology. As college lecturers strive to promote excellence within their classrooms, educational technology will help promote their cause. Once educational technology is integrated correctly, it can provide the students with efficiency and higher test scores (Hart \& Laher, 2015). However, Ozerbas and Erdogan (2016) disagreed with this statement and shared that the use of technology innovation does not necessarily mean that students will achieve better learning and results.

Within the school system, tests are generally used to evaluate students' progress or ability to understand what has been taught. One of the methods frequently used is standardized testing. This form of testing is used in today's classroom for evaluating learning outcomes. These tests are typically done using paper and pencil test format. However, through educational technology, a more authentic way of testing can be carried out. This may include the use of concept mapping, blogs, wikis, podcasting, using Moodle and other web tools that will promote learning, creativity, and reinforcement (Wade et al., 2013).

Gardner (2003) discovered that all students do not learn the same. Some students may be visual learners, while others are kinesthetic learners. He further shared that there are seven different types of intelligence. However, when lecturers are assessing or preparing for testing, these intelligence bits are disregarded since the time frame necessary to perform these skills is not allowed

Pedulla et al. (2003) revealed that college lecturers' pressures while doing standardized testing affect how they carry out their instructional practices. It was also revealed that college lecturers might be guilty of teaching only what they plan on testing. Thus, only touching the surface instead of providing students with in-depth learning so that students can have a more extensive inquiry base. Moreover, through inquiry-based learning, students take an active role in their learning and use technology to open this door. Students no longer must rely on college lecturers to provide them with all the information; they can now use technology to expand their knowledge. This can be achieved through problem-based learning, virtual field trips, and the flipped classroom.

College lecturers support educational technology. However, their unwillingness stems from the barriers they face instead of the concept of technology (Arsić \& Milovanović, 2016). Nonetheless, there is a gap within the literature regarding the lack of observation evidence among college lecturers and their new pedagogical knowledge around technology adoption. A further gap regarding how technology relates to transforming lecturer performance and the outcome of students' performance is also needed (Westberry et al., 2015). Similarly, there is limited evidence as to the change that professional development has on college lecturers regarding the implementation of educational technology among college lecturers and their technology engagement (Durff \& Carteer, 2019). Even with these disparities, one thing is for certain that college lecturers' role and attitude are of utmost importance in the integration process (Arsić \& Milovanović, 2016; Buabeng-Andoh, 2012; Deng et al., 2014; Ertmer et al., 2012). Subsequently, college lecturers' roles cannot be minimized in the process of educational technology because they are central to sustaining and instituting change within the educational process.

\section{Research Question and Methodology}

The research question for the study is: What are college lecturers' beliefs about barriers to technology adoption 
at Zendejay College and necessary supports they feel would be needed to overcome these barriers? The study consisted of a Basic Qualitative study and its aim was to understand a college within the Caribbean named Zendejay College. Zendejay college is located in Antigua and Barbuda. The study looked at the barriers faced by college lecturers in higher learning and the support they felt was needed

The sample size for the study were eight lecturers from the Zendejay College and all persons answered the research questions and provided an understanding into the phenomenon being investigated. The college lecturers were taken from the various department at Zendejay College. This included: The Department of Education, the Department of Business, the Department of Pharmacy, and the Department of Undergraduate Studies. Interviews were the instrument used to collect data from the participants and the interview questions were designed to answer the research questions and provided credence to the conceptual framework and literature review. Moreover, all 8 of the interviews were conducted over the telephone and consisted of 20 questions. The allotment of time given for each interview was a minimum of 30 and all interviews were conducted within a 2weeks period.

\section{Discussion of the Results}

The study looked at the Barriers to Technology Adoption the college lecturers experience and the support lecturers felt were needed.

The study found that all eight lectures from the Zendehay College shared several barriers that they faced and impair their ability to adopt technology effectively. The barriers were classified into two categories. These categories were Extrinsic barriers and Intrinsic barriers. Extrinsic barriers refer to anything that is not suitable to the formation of an ICT infrastructure. Examples of extrinsic barriers include training, time, insufficient support, lack of technological pedagogical content knowledge and institutional policy, attitude, beliefs, or resistance. Intrinsic barriers refer to lecturers' personal beliefs.

\section{Extrinsic Barriers}

Six out of eight lecturers identified they engaged in infrastructure issues that hamper their technology adoption at the college. It was expressed by lecturers that sometimes the Internet is turned off by the college. When the Internet is not readily available it impacts the students. Sometime lecturers may have internet access, but then sometimes students may not.

Infrastructure issues such as plugs, and proper planning towards incorporating technology is a miss. Lecturers further shared that because there is so much curriculum that they need to go through they don't have time for interruptions. Planning takes a lot of time; technology adoption makes planning very difficult because nobody has that kind of time to constantly plan. Lecturers further identified that there's no real policy here and no one is there to enforce lecturers to use technology within the classroom. The results also shared that the LMS Moodle servers at times were not dependable, which then makes planning very difficult for lecturers. Lastly, The infrastructure needs improving if lecturers are going to move towards an online modality. This means that the plugs, the electricity, the wiring which is very faulty, needs to improve.

\section{The Need for Training}

Four out of the eight lecturers shared that training was needed to be progressive in adopting technology within the classroom. Even though professional development is done at the college, this form of training or professional development for a want of a better word may not be applicable to lecturer's technology adoption. The proposed training does not focus on educational technology and if they do it is not for long periods. The present form of professional development is not sustainable for the administrators' objective is to cram information in a shorter time frame. However, lecturers felt that this ideology is a myth. Training must be ongoing, so that confidence level can be built. If lecturers are able to practice using the technology, it would improve lecturer's competency skills and raise their self-efficacy causing lecturers to alleviate the barriers.

\section{Time as Barrier}

Three out of eight lecturers spoke of how time is a barrier that they face while adopting technology. The lecturers shared that the college curriculum is very demanding and that experimenting with technology is very time-consuming. The Lecturers have a responsibility to cover all of the materials prescribed in the curriculum within a very short time, and in some departments, programs are evaluated by an external body such as CAPE and UWI. As a result, lecturers need to cover all the syllabus contents so that students can be adequately prepared for their subject.

Need for Support

All of the eight lecturers were in support that lecturers are in need of support at the college.

Administrative Support. Six of the eight participants showed that administration support is vital to combatting technology barriers. Adequate support from Heads of Department was deemed as necessary by participants when attempting to adopt technology. Often, the department heads are the ones who may or may not feel that technology-based learning is not important. This lack of support from Administration and or Heads of Department may cause lecturers to log heads with one another, causing the lecturer to feel frustrated, 
unappreciated, and burnt out, resorting in teacher-centred learning, avoidance and a negative attitude that will influence the lecturer behavior.

Participants shared that they have the option to use technology or not. All lecturers had a right to decide how deep and far they were willing to use their technology. However, it was only through the pandemic of COVID-19 that the participants were forced to go online and use technology exclusively. This was increasingly difficult because lecturers were forced to use tools that they have never experienced before. Participants pointed out that they "felt alone." For others, their experience could be described as a form of defibrillator that was used to shock their heart to this new way of forced teaching. It was also expressed that they were forced to toe the line with the use of technology even if they had no prior experience with it. Lecturers had no choice but to use the technology for the students had to receive content knowledge in preparation for the end of school exam and. external examination. Lecturers further explained that the Administration should implement an institutional policy. By this implementation, the Administration would ensure that the resources and infrastructure align with the policy and that the much-needed equipment to support technology adoption will be bought.

\section{Conclusion}

There were indeed barriers that lecturers are facing at the Zendejay College. These barriers can be seen as either intrinsic and extrinsic barriers or both. These challenges have hampered the lecturers with their adoption. Some examples of these barriers included equipment, proper infrastructure, time constraint, financial restraints, personal issues, attitude toward technology use, lack of technology knowledge, and the challenges technology will impose. It was also revealed that the college's support system was minimal and that lecturers needed more support if they were to be more effective in technology adoption.

It was also identified that every lecturer needs some form of support. Even though the research focus was on lecturers' issues it was brought to light that students need support for adoption to be successful. It is often assumed that students of today are more advanced, have all the technology gadgets and equipment and are more technologically incline; however, these generalizations may not necessarily be accurate. Zendejay College lecturers felt that having support from the college administration was important. They also shared that having an educational support team was necessary to be created. The participants expressed that more effort was needed at Zendejay college with training and keeping lecturers updated with the new technology trends. For the more training they received, the more their self-efficacy improved. But more importantly, ensuring that the resources and infrastructure be up to standards to support lecturers and students.

\section{Declaration of Conflicting Interests}

The author(s) declared no potential conflicts of interest with respect to the research, authorship, and/or publication of this article.

\section{Funding}

The author(s) received no financial support for the research, authorship, and/or publication of this article.

\section{References}

Alemu, B. M. 2015. Integrating ICT into teaching-learning practices: Promise, challenges and future directions of higher educational institutes. Universal Journal of Educational Research, 3(3), 170-189. http://files.eric.ed.gov/fulltext/EJ1056082.pdf

Alkahtani, A. 2017. The challenges facing the integration of ICT in teaching in Saudi secondary schools. International Journal of Education and Development using ICT, 13(1)

Arcelay-Rojas, Y. A. 2018. Using focus groups to explore sources of self-efficacy in Puerto Rican preservice teachers. Journal of Educational Research and Practice, 8(1), Article 10. https://doi.org/10.5590/JERAP.2018.08.1.10

Bandura, A. 1977. Self-efficacy: Toward a unifying theory of behavioral change. Psychological Review, 84(2), 191-215. https://doi.org/10.1037/0033-295X.84.2.191

Bandura, A. 1986. The explanatory and predictive scope of self-efficacy theory. Journal of Social and Clinical Psychology, 4(3), 359-373. https://doi.org/10.1521/jscp.1986.4.3.359

Bandura, A. 1997. Self-efficacy: The exercise of control. Macmillan.

Bandura, A. 1998. Personal and collective efficacy in human adaptation and change. In J. G. Adair, D. Belanger, \& K. L. Dion (Eds.), Advances in psychological science: Vol. 1. Personal, social, and cultural aspects (pp. 51-71). Psychology Press.

Bandura, A., Barbaranelli, C., Caprara, G. V., \& Pastorelli, C. (1996). Multifaceted impact of self-efficacy beliefs on academic functioning. Child Development, 67(3), 1206-1222. https://doi.org/10.1111/j.14678624.1996.tb01791.x

Becuwe, H., Tondeur, J., Pareja Roblin, N., Thys, J., \& Castelein, E. 2016. Teacher design teams as a strategy for professional development: The role of the facilitator. Educational Research and Evaluation, 22(3-4), 
141-154. https://doi.org/10.1080/13803611.2016.1247724

Bozbayindir, F., \& Alev, S. 2019. An analysis of the relationship between the general self-efficacy perceptions of teachers and their political skill levels. International Journal of Progressive Education, 15(2), 65-77. http://files.eric.ed.gov/fulltext/EJ1219211.pdf

Castro, W. 2016, March 7-9. An activity theory approach to study barriers of faculty regarding technology integration. In Proceedings of INTED2016 Conference, Valencia, Spain (pp. 7232-7241). https://tinyurl.com/yd8sxgy2

Castro, W. F., \& Nyvang, T. 2018. From professors' barriers to organizational conditions in ICT integration in higher education. Tidsskriftet Laring og Medier, 11(18). https://doi.org/10.7146/lom.v10i18.96143

Chemers, M. M., Hu, L. T., \& Garcia, B. F. 2001. Academic self-efficacy and first year college student performance and adjustment. Journal of Educational psychology, 93(1), 55-64. https://doi.org/10.1037/0022-0663.93.1.55

Daniel, J. 2020. Education and the COVID-19 pandemic. Prospects, 49(1), 91-96.

Delgado, A. J., Wardlow, L., McKnight, K., \& O’Malley, K. 2015. Educational technology: A review of the integration, resources, and effectiveness of technology in K-12 classrooms. Journal of Information Technology Education, 14, 397-416. http://jite.informingscience.org/ documents/Vol14/JTEv14ResearchP397-416Delgado1829.pdf

Durff, L., \& Carter, M. 2019. Overcoming Second-Order Barriers to Technology Integration in K-5 Schools. Journal of Educational Research and Practice, 9(1), 17.

Ertmer, P. A., \& Ottenbreit-Leftwich, A. T. 2010. Teacher technology change: How knowledge, confidence, beliefs, and culture intersect. Journal of Research on Technology in Education, 42(3), 255-284. https://doi.org/10.1007/BF02504683

Ertmer, P. A., Addison, P., Lane, M., Ross, E., \& Woods, D. 1999. Examining teachers' beliefs about the role of technology in the elementary classroom. Journal of Research on Computing in Education, 32(1), 54-72. https://doi.org/10.1080/08886504.1999.10782269

Ertmer, P. A., Ottenbreit-Leftwich, A. T., Sadik, O., Sendurur, E., \& Sendurur, P. 2012. Teacher beliefs and technology integration practices: A critical relationship. Computers \& Education, 59(2), 423-435.

Farjon, D., Smits, A., \& Voogt, J. 2019. Technology integration of pre-service teachers explained by attitudes and beliefs, competency, access, and experience. Computers \& Education, 130, 81-93.

Fishbein, M., \& Ajzen, I. 2010. Predicting and changing behavior: The reasoned action approach. Psychology Press

Gardner, H. 2003. Intelligence in seven steps. New Horizons for Learning. http://ocmatours.net/wpcontent/uploads/2007/Gardner.pdf

Guzmán, W. C. 2018. A change laboratory professional development intervention to motivate university teachers to identify and overcome barriers to the integration of ICT. Outlines: Critical Practice Studies, 19(1), 6790. https://tidsskrift.dk/outlines/article/view/105531

Hart, S. A., \& Laher, S. 2015. Perceived usefulness and culture as predictors of teachers' attitudes toward educational technology in South Africa. South African Journal of Education, 35(4). https://doi.org/10.15700/saje.v35n4a1180

.Hew, K. F., \& Brush, T. 2007. Integrating technology into K-12 teaching and learning: Current knowledge gaps and recommendations for future research. Educational Technology Research and Development, 55(3), 223252. https://doi.org/10.1007/s11423-006-9022-5

Hoy, A. W., Hoy, W. K., \& Davis, H. A. 2009. Teachers' self-efficacy beliefs.

Hsu, S. 2010. The relationship between teacher's technology integration ability and usage. Journal of Educational Computing Research, 43(3), 309-325. https://doi.org/10.2190/EC.43.3.c

Hur, J. W., Shannon, D., \& Wolf, S. 2016. An investigation of relationships between internal and external factors affecting technology integration in classrooms. Journal of Digital Learning in Teacher Education, 32(3), 105-114. https://doi.org/10.1080/21532974.2016.1169959

Inan, F. A., \& Lowther, D. L. 2010. Factors affecting technology integration in K-12 classrooms: A path model. Educational Technology Research and Development, 58(2), 137-154. https://doi.org/10.1007/s11423-0099132-y

Jamal, A. A., \& Khasawneh, S. 2011. Jordanian pre-service teachers' and technology integration: A human resource development approach. Journal of Educational Technology \& Society, 14(4), 77-87. https://www.jstor.org/stable/pdf/jeductechsoci.14.4.77.pdf

Januszewski, A., \& Molenda, M. 2008. Educational technology: A definition with commentary. Erlbaum.

Jarrahi, M. H. 2018. Artificial intelligence and the future of work: Human-AI symbiosis in organizational decision making. Business Horizons, 61(4), 577-586. https://doi.org/10.1016/j.bushor.2018.03.007

Kale, U., \& Goh, D. 2014. Teaching style, ICT experience and teachers' attitudes toward teaching with Web 2.0. Education and Information Technologies, 19(1), 41-60. https://doi.org/10.1007/s10639-012-9210-3 
Kearney, M., Schuck, S., Aubusson, P., \& Burke, P. F. 2018. Teachers' technology adoption and practices: lessons learned from the IWB phenomenon. Teacher Development, 22(4), 481-496. https://doi.org/10.1080/13664530.2017.1363083

Keengwe, J., \& Maxfield, M. B. 2015. Advancing higher education with mobile learning technologies: Cases, trends, and inquiry-based methods. Information Science Reference.

Khan, S., Hasan, M., \& Clement, C. 2012. Barriers to the introduction of ICT into education in developing countries: The example of Bangladesh. International Journal of Instruction, 5(2), 61-80. http://files.eric.ed.gov/fulltext/ED533790.pdf

Khodabandelou, R., That, J. E. M., Selvaraju, M. A., Ken, T. Y., Kewen, Z., Yan, Z., \& Ning, T. Y. (2016). Exploring the main barriers of technology integration in the English language teaching classroom: A qualitative study. International Journal of Education and Literacy Studies, 4(1), 53-58. https://doi.org/10.7575/aiac.ijels.v.4n.1p.53

Kim, C., Kim, M. K., Lee, C., Spector, J. M., \& DeMeester, K. (2013). Teacher beliefs and technology integration. Teaching and Teacher Education, 29, 76-85. https://doi.org/10.1016/j.tate.2012.08.005

Kimmons, R., \& Hall, C. 2016. Toward a broader understanding of teacher technology integration beliefs and values. Journal of Technology and Teacher Education, 24(3), 309-335.

Kozma, R. B. 2002. ICT and educational reform in developed and developing countries. Center for Technology in Learning, SRI International. https://citeseerx.ist.psu.edu/viewdoc/download?doi=10.1.1.135.2867\&rep=rep1\&type=pdf

Krause, J. M. 2017. Physical education student teachers' technology integration self-efficacy. Physical Educator, 74(3), 476-496. https://doi.org/10.18666/TPE-2017-V74-I3-7329

Krause, M., Pietzner, V., Dori, Y. J., \& Eilks, I. 2017. Differences and developments in attitudes and selfefficacy of prospective chemistry teachers concerning the use of ICT in education. Eurasia Journal of Mathematics, Science and Technology Education, 13(8), 4405-4417. https://doi.org/10.12973/eurasia.2017.00935a

Kul, U. 2018. Influences of Technology Integrated Professional Development Course on Mathematics Teachers. European Journal of Educational Research, 7(2), 233-243. http://files.eric.ed.gov/fulltext/EJ1175354.pdf

Kut, U. 2018. Influences of technology integrated professional development course on mathematics teachers. European Journal of Educational Research, 7(2), 233-243. http://files.eric.ed.gov/fulltext/EJ1175354.pdf

Laine, T. H., \& Nygren, E. 2015. Technology integration in next generation mobile learning. In J. Traxler \& A. Kukulska-Hulme (Eds.), Mobile learning: Next generation (pp. 81-99). Routledge.

Lawrence, J. E., \& Tar, U. A. 2018. Factors that influence teachers' adoption and integration of ICT in teaching/learning process. Educational Media International, 55(1), 79-105. https://doi.org/10.1080/09523987.2018.1439712

Lee, Y., \& Lee, J. 2014. Enhancing pre-service teachers' self-efficacy beliefs for technology integration through lesson planning practice. Computers \& Education, https://doi.org/10.1016/j.compedu.2014.01.001

Lemon, N., \& Garvis, S. 2016. Pre-service teacher self-efficacy in digital technology. Teachers and Teaching, 22(3), 387-408. https://doi.org/10.1080/13540602.2015.1058594

Lowther, D. L., Inan, F. A., Strahl, D. J., \& Ross, S. M. 2008. Does technology integration "work" when key barriers are removed? Educational Media International, 45(3), 195-213. https://doi.org/10.1080/09523980802284317

Machado, L. J., \& Chung, C. J. 2015. Integrating technology: The principals' role and effect. International Education Studies, 8(5), 43-53. https://doi.org/10.5539/ies.v8n5p43

MacKinnon, P. C., \& MacKinnon, G. 2013. Technology integration in developing countries: A case study of higher education in Jamaica. International Journal of Technology, Knowledge \& Society, 9(1), 51-59.

Margolis, H., \& McCabe, P. P. 2004. Self-efficacy: A key to improving the motivation of struggling learners. The Clearing House: A Journal of Educational Strategies, Issues and Ideas, 77(6), 241-249. https://doi.org/10.1080/10459880309603362

Masingila, O., Khatete, W., Maundu, N., Foley, R., Ndethiu, M., \& Twoli, W. 2019. From implementation to efficacy: Factors affecting Kenyan secondary teachers' technology integration. Africa Education Review, 16(1), 58-87. https://doi.org/10.1080/18146627.2016.1224574

Moller, L., Foshay, W. R., \& Huett, J. 2008. Implications for instructional design on the potential of the web. TechTrends, 52(4), 66-70. https://doi.org/10.1007/s11528-008-0179-0

Moreillon, J. 2009. Learning and teaching in WANDA wiki wonderland: Literature circles in the digital commons. Teacher Librarian, 37(2), 23-28.

Nikolopoulou, K., \& Gialamas, V. 2016a. Barriers to ICT use in high schools: Greek teachers' perceptions. Journal of Computers in Education, 3(1), 59-75. https://doi.org/10.1007/s40692-015-0052-z

Nikolopoulou, K., \& Gialamas, V. 2016b. Exploring secondary school pupils' ICT engagement: A validation 
study. Creative Education, 7(4), 567-573. https://doi.org/10.4236/ce.2016.74059

Onuoha, C., Onuoha, P., \& Ferdinand-James, D. 2016. Caribbean teachers' perspectives on one-to-one ICT programme for enhancing teaching and learning: A case study of boys' high school. Journal of Educational Policy and Entrepreneurial Research, 3(7), 28-42. https://tinyurl.com/y7ktthak

Oskay, Ö. Ö. 2017. An investigation of teachers' self-efficacy beliefs concerning educational technology standards and technological pedagogical content knowledge. Eurasia Journal of Mathematics, Science and Technology Education, 13(8), 4739-4752. https://doi.org/10.12973/eurasia.2017.00961a

Özdemir, S. 2017. Teacher views on barriers to the integration of information and communication technologies (ICT) in Turkish teaching. International Journal of Environmental and Science Education, 12(3), 505-521. https://doi.org/10.12973/ijese.2017.1244p

Ozerbas, M. A., \& Erdogan, B. H. 2016. The effect of the digital classroom on academic success and online technologies self-efficacy. Educational Technology \& Society, 19(4), $203-212$. https://www.jstor.org/stable/pdf/jeductechsoci.19.4.203.pdf

Prensky, M. 2008. The role of technology in teaching and the classroom. Educational Technology, 48(6). https://marcprensky.com/writing/Prensky-The_Role_of_Technology-ET-11-12-08.pdf

Prensky, M. 2014. The world needs a new curriculum: It's time to lose the "proxies" and go beyond "21st century skills" - and get all students in the world to the real core of education. Educational Technology, 54(4), 3-15. $\quad$ https://marcprensky.com/wp-content/uploads/2013/05/Prensky-5-TheWorld_Needs_a_New_Curriculum.pdf

Ramorola, M. Z. 2014. Challenge of effective technology integration into teaching and learning. Africa Education Review, 10(4), 654-670. https://doi.org/10.1080/18146627.2013.853559

Robinson, R. 2016. Delivering a medical school elective with massive open online course (MOOC) technology. PeerJ, 4, e2343.

Robinson, D. E., \& Wizer, D. R. 2016. Universal Design for Learning and the Quality Matters guidelines for the design and implementation of online learning events. International Journal of Technology in Teaching and Learning, 12(1), 17-32. http://files.eric.ed.gov/fulltext/EJ1213328.pdf

Rogers, E. M. 1995. Diffusion of Innovations: modifications of a model for telecommunications. In Die diffusion von innovationen in der telekommunikation (pp. 25-38). Springer, Berlin, Heidelberg.

Rogers, E. M. 2003. Diffusion of innovations (5th ed.). Free Press.

Rogers, E. M. 2005. Adoption of innovation.

Rogers, E. M. 2010. Diffusion of innovations (4th ed.). Simon and Schuster.

Rogers, E. M., Medina, U. E., Rivera, M. A., \& Wiley, C. J. 2005. Complex adaptive systems and the diffusion of innovations. Innovation Journal: The Public Sector Innovation Journal, 10(3), 1-26. http://citeseerx.ist.psu.edu/viewdoc/download?doi=10.1.1.130.8047\&rep=rep1\&type=pdf

Rusek, M., Stárková, D., Chytrý, V., \& Bílek, M. 2017. Adoption of ICT innovations by secondary school teachers and pre-service teachers within chemistry education. Journal of Baltic Science Education, 16(4), 510-523. https://tinyurl.com/ycekg2kg

Sadaf, A., Newby, T. J., \& Ertmer, P. A. 2012. Exploring pre-service teachers' beliefs about using Web 2.0 technologies in K-12 classroom. Computers \& Education, 59(3), 937-945.

Saxena, A. 2017. Issues and impediments faced by Canadian teachers while integrating ICT in pedagogical practice. Turkish Online Journal of Educational Technology, 16(2), 58-70. http://files.eric.ed.gov/fulltext/EJ1137791.pdf

Schunk, D. H. 1995. Self-efficacy and education and instruction. In J. E. Maddux (Ed.), Self-efficacy, adaptation, and adjustment: Theory, research, and application. (pp. 281-303). Plenum Press.

Smith, M. 2020. Integrating technology in contemporary legal education. The Law Teacher, 54(2), $209-221$. https://doi.org/10.1080/03069400.2019.1643647

Trucano, M. 2009. What do we know about the effective uses of information and communication technologies in education in developing countries? In F. Scheuermann \& F. Pedró (Eds.), Assessing the effects of ICT in education (pp. 61-68). Publications Office of the European Union.

Tsai, C. C., \& Chai, C. S. 2012. The "third"-order barrier for technology-integration instruction: Implications for teacher education. Australasian Journal of Educational Technology, 28(6). https://doi.org/10.14742/ajet.810

Van Niekerk, M., \& Blignaut, S. 2014. A framework for Information and Communication Technology integration in schools through teacher professional development. Africa Education Review, 11(2), $236-253$. https://doi.org/10.1080/18146627.2014.927159

Wade, W. Y., Rasmussen, K. L., \& Fox-Turnbull, W. 2013. Can technology be a transformative force in education? Preventing School Failure: Alternative Education for Children and Youth, 57(3), 162-170. https://doi.org/10.1080/1045988X.2013.795790

Xia, B. S. 2017. An in-depth analysis of teaching themes and the quality of teaching in higher education: 
Evidence from the programming education environments. International Journal of Teaching and Learning in Higher Education, 29(2), 245-254. http://files.eric.ed.gov/fulltext/EJ1146146.pdf

About the author: Dr. N. Williams-Buffonge is a Canadian born and holds a Ph.D. in Education specializing in Educational Technology from Walden University. She has more than 22 years of teaching experience. Currently, she is a lecturer at the University of the West Indies and a Practicum Supervisor at the University of the West Indies Open Campus. She also achieved her MSc degree with Walden University and obtained a Bachelor of Arts and Education at York University in Toronto, Canada. Her main interest area is ICT and education and digital literacy. 